\title{
Elevated Cortisol and/or Simple Carbohydrates in Stress and Stress-Related Diseases
}

\author{
Muhammad Torequl Islam* \\ Department of Pharmacy, Southern University Bangladesh, Bangladesh
}

Submission: November 6, 2017; Published: December 01, 2017

*Corresponding author: Muhammad Torequl Islam, Department of Pharmacy, Southern University Bangladesh, Mehedibag (Chittagong)- 4000, Bangladesh, Email: rbiotufpi.br@gmail.com

\section{Opinion}

Cortisol, a steroid hormone, in the glucocorticoid class is produced in humans by the zona fasciculata of the adrenal cortex within the adrenal gland [1] and released in response to stress and low blood-glucose concentration [2]. It represents a potentially important mechanism linking chronic stress with accelerated aging. In a study, a 24-hour urinary excretion of cortisol was found to link with an elevated marker of DNA and RNA damage in older adults [3]. Previously, Du et al. [4] reported that, long-term high-dose cortisol administration dramatically decreased mitochondrial function and promoted cell death in culture cells.

In the early fasting state, cortisol stimulates gluconeogenesis (formation of glucose from non-carbohydrate source), and activates anti-stress and anti-inflammatory pathways. Cortisol also plays an important role in liver and muscle glycogenolysis (glycogen to glucose-1-phosphate and glucose) [5]. However, in the late fasting state, cortisol increases glycogenesis, where the livers takes up glucose not being used by the peripheral tissue and turn it into liver glycogen stores to be used by the body during fasting state [6]. In the later case, cortisol counteracts insulin and contributes insulin resistance [7] by decreasing the translocation of glucose transporters, especially insulin-sensitive glucose transporter (GLUT)-4 to the cell membrane [8].

Glucose is a major circulating sugar and primary fuel for the animal brain for energy production. Not only GLUT-1, but also GLUT-4 also helps to enter glucose into neural cells [9]. Thus, an increase in cortisol level contributes stress in the animal's brain. The fight or flight response to emergency or stress involves glycogenolysis, gluconeogenesis, and so on decrease motility of the digestive system, cause secretion of the cortisol [10]. Hyperglycemia is evident to contribute to cellular and tissue injury by increasing oxidative stress (by overproduction of ROS, such as superoxide radical) and cause DNA damage [11,12]. In a study, cisplatin was found to induce nephrotoxicity in rat renal cortical slices, where a reduction in gluconeogenesis was seen along with the down-regulation of reduced glutathione (GSH), while up-regulation of lipid peroxides (LPx) [13]. In this study, it was seen that the amino acids such as glycine and L-arginine showed the promising nephroprotective capability as they reduced LPx, while increased in GSH levels in the experimental animals. An excess of fructose and glucose in the bloodstream causes extensive glycation and damage the proteins [14]. Advanced glycated products (AGEs) play a critical role in aging, diabetes, atherosclerosis and cardiovascular diseases, and in neurodegenerative diseases. Some of these AGEs are also reported to link with an increased fatty acid oxidation in arterial endothelial cells $[15,16]$.

The polyol pathway transforms excess of glucose into sorbitol, which in turn produces a variety of intracellular changes in vascular tissues, including conversion of glucose to fructose by sorbitol dehydrogenase [17]. Fructose at high concentration can increase reactive oxygen species (ROS) production [18], that can cause excessive cytokine (pro- and/or inflammatory) production, thus the inflammatory response. Excess ROS is also evident to cause damage of proteins, lipids, and genetic materials (e.g. DNA and RNA). ROS can alter signal transduction and cause insulin resistance via mitogen-activated protein kinase (MAPK), protein kinase $\mathrm{C}$ (PKC) and c-Jun N-terminal kinase (JAK) mediated pathways.

Diabetes is characterized by an increased production of sorbitol, that can induce nitric oxide synthase (iNOS), reactive oxygen/nitrogen species (ROS/RNS); cause oxidative-nitrosative stress, endogenous antioxidant depletion, enhanced lipid peroxidation, and so on [19].

Substances such as methylglyoxal (MG) cause insulin resistance [20] may associate with an induction of hypertension [21], which can increase the levels of uric acid [22], thus the increase in nicotinamide adenine dinucleotide phosphate (NADPH) oxidase activity and oxidative stress [23].

In summary, simple carbohydrates after ingestion readily available in the blood, increase cortisol to let them convert into 
glycogen. Both, glycogenolysis and gluconeogenesis are also invloved in stress induction by multiple pathways. Moreover, hyperglycemia is also evident to induce oxidative stress in human and other animals, by increasing glycation and increase in fatty acid oxidation.

\section{References}

1. Scott E (2011) Cortisol and Stress: How to Stay Healthy.

2. Hoehn K, Marieb EN (2010) Human Anatomy \& Physiology. San Francisco: Benjamin Cummings.

3. Joergensen A, Broedbaek K, Weimann A, Semba RD, Ferrucci L, et al. (2011) Association between urinary excretion of cortisol and markers of oxidatively damaged DNA and RNA in humans. PLoS One 6(6): e20795.

4. Du J, Wang Y, Hunter R, Wei Y, Blumenthal R et al. (2009) Dynamic regulation of mitochondrial function by glucocorticoids. Proc Natl Acad Sci U S A 106(9): 3543-3548.

5. Martin PA, Crump MH (2003) The adrenal gland, In: Dooley MP, Pineda MH (Eds) In: McDonald's veterinary endocrinology and reproduction $\left(5^{\text {th }}\right.$ edn), Ames, Iowa: Iowa State Press.

6. Baynes J, Dominiczak M (2009) Medical biochemistry. Mosby Elsevier.

7. Brown DF, Brown DD (2003) USMLE Step 1 Secrets: Questions You Will Be Asked on USMLE Step 1. Hanley \& Belfus: Philadelphia.

8. King MB (2005) Lange Q \& A. McGraw-Hill, Medical Pub Division, New York, USA.

9. Cha SH, Wolfgang M, Tokutake Y, Chohnan S, Lane MD (2008) Differential effects of central fructose and glucose on hypothalamic malonyl-CoA and food intake. Proc Natl Acad Sci USA 105(44): 1687116875 .

10. McCorry LK (2007) Physiology of the Autonomic Nervous System. Am J Pharm Edu 71(4): 78.

11. Du X, Matsumura T, Edelstein D, Rossetti L, Zsengeller Z, et al. (2003) Inhibition of GAPDH activity by poly(ADP-ribose) polymerase activates three major pathways of hyperglycemic damage in endothelial cells. J Clin Invest 112(7): 1049-1057.

12. Angeli F, Reboldi G, Poltronieri C, Aita A, Bartolini C, et al. (2015) Detrimental Effects of Hyperglycemia in Acute Coronary Syndromes: from
Pathophysiological Mechanisms to Therapeutic Strategies. Mini Rev Med Chem 15(14): 1164-1173.

13. Mahran YF, Khalifa AE, El-Demerdash E (2011) A comparative study of protective mechanisms of glycine and L-arginine against cisplatin-induced nephrotoxicity in rat renal cortical slices. Drug Discov Ther 5(1): $32-40$.

14. Kikuchi S, Shinpo K, Takeuchi M, Yamagishi S, Makita Z, et al. (2003) Glycation-a sweet tempter for neuronal death. Brain Res Brain Res Rev 41(2-3): 306-323.

15. Suji G, Sivakami S (2004) Glucose, glycation and aging. Biogerontology 5(6): 365-373.

16. Wautier JL, Schmidt AM (2004) Protein glycation: a firm link to endothelial cell dysfunction. Circ Res 95(3): 233-238.

17. Santos GC, Zeidler JD, Pérez-Valencia JA, Sant'Anna-Silva ACB, Da Poian AT, et al. (2017) Metabolomic Analysis Reveals Vitamin D-induced Decrease in Polyol Pathway and Subtle Modulation of Glycolysis in HEK293T Cells. Sci Rep 7: 9510.

18. Madlala HP, Maarman GJ, Ojuka E (2016) Uric acid and transforming growth factor in fructose-induced production of reactive oxygen species in skeletal muscle. Nutr Rev 74(4): 259-266.

19. Aquilano K, Filomeni G, Di Renzo L, Vito Md, Stefano Cd, et al. (2007) Reactive oxygen and nitrogen species are involved in sorbitol-induced apoptosis of human erithroleukaemia cells K562. Free Radic Res 41(4): 452-460.

20. Dhar A, Dhar I, Jiang B, Desai KM, Wu L (2011) Chronic methylglyoxal infusion by minipump causes pancreatic beta cell dysfunction and induces type 2 diabetes in Sprague-Dawley rats. Diabetes 60(3): 899908.

21. Wang X, Desai K, Chang T, Wu L (2005) Vascular methylglyoxal metabolism and the development of hypertension. J Hypertens 23(8): 15651573.

22. Yoo HG, Lee SI, Chae HJ, Park SJ, Lee YC, et al. (2009) Prevalence of insulin resistance and metabolic syndrome in patients with gouty arthritis. Rheumatol Int 20: 231-235.

23. Lee MY, Martin AS, Mehta PK, Dikalova AE, Garrido AM, et al. (2009) Mechanisms of vascular smooth muscle NADPH oxidase 1(Nox1) contribution to injury-induced neointimal formation. Arterioscler Thromb Vasc Biol 29(4): 480-487.

This work is licensed under Creative Commons Attribution 4.0 Licens DOI: 10.19080/CTCMI.2017.02.555583

\section{Your next submission with Juniper Publishers} will reach you the below assets

- Quality Editorial service

- Swift Peer Review

- Reprints availability

- E-prints Service

- Manuscript Podcast for convenient understanding

- Global attainment for your research

- Manuscript accessibility in different formats

( Pdf, E-pub, Full Text, Audio)

- Unceasing customer service

Track the below URL for one-step submission

https://juniperpublishers.com/online-submission.php 